\title{
KONSTRUKSI PENALARAN STATISTIS \\ PADA STATISTIKA PENELITIAN
}

\author{
Yusfita Yusuf \\ nugrahayusfita@yahoo.co.id \\ Program Studi Pendidikan Matematika STKIP Sebelas April Sumedang
}

\section{ABSTRACT \\ Statistical Reasoning Construction On Statistics Research}

\begin{abstract}
Statistics can be viewed as a tool to solve problems that always occur in everyday life,workplace, and science. Based on the observation on the students, it was found that the there was statistical reasoning abilities of different students. This could be demonstrated by the acquisition of the different test scores, in which there were students who just copy the questions until finishing the work on the problems given. This study discussesed the development deduction level / degree of statistical reasoning skills based on understanding and opinion of several experts, which were constructed based on the results of a case study of mathematics education on STKIP students of Sebelas April Sumedang with statistical research material.
\end{abstract}

Keyword: Statistical Reasoning, Level of Statistical Reasoning

\section{PENDAHULUAN}

Statistika dapat dipandang sebagai alat untuk memecahkan masalah yang senantiasa terjadi dalam kehidupan sehari-hari, di tempat kerja, dan di dalam ilmu pengetahuan (Moore, 1997). Secara khusus, statistika digunakan untuk menguraikan dan memprediksi fenomena dengan menggunakan kumpulan hasil dari pengukuran. Kemampuan statistis diperlukan untuk dapat menafsirkan dan memahami serta membuat keputusan yang baik untuk data-data hasil pengukuran tersebut. Hal ini sejalan dengan pendapat Rumsey (2002) bahwa tujuan dari pembelajaran statistika adalah siswa mengerti statistika dengan baik agar dapat mendapat informasi dari data yang ada, mengkritik dan membuat keputusan berdasarkan informasi tersebut serta bertujuan untuk mengembangkan keterampilan penelitian. Salah satu dari kemampuan statistis adalah penalaran statistis.

Chervaney (Garfield, 2002) mendefinisikan penalaran statistis sebagai apa yang dapat dilakukan siswa dengan konten statistis dan menggunakan keterampilannya dalam menggunakan konsep statistis untuk penyelesaian masalah yang statistika. Mereka melihat penalaran statistis sebagai proses yang terdiri dari tiga langkah berikut: (1) komprehensi, (2) perencanaan dan pengambilan keputusan, dan (3) evaluasi dan interpretasi.

Berdasarkan hasil penelitian yang dilakukan oleh Martadipura (2012) menunjukkan bahwa mahasiswa S1 Jurusan Pendidikan Matematika di sebuah PTN di Bandung memiliki kemampuan yang rendah dalam statistika dasar. Informasi tambahan diperoleh dari observasi awal yang dilakukan penulis terhadap mahasiswa program Studi Pendidikan Matematika semester VI tahun ajaran 2015/2016, dimana mahasiswa dalam satu kelas mempunyai kemampuan penalaran statistis yang berbeda. Hal ini dapat ditunjukkan dengan perolehan nilai ujian yang berbeda, dimana ada mahasiswa yang menyalin soal saja sampai yang mengerjakan soal secara lengkap. Oleh karena itu perlu 
dilakukan suatu pendekatan untuk mengetahui level/ tingkat bernalar seseorang seperti yang dikemukakan oleh ahli. Adapun pengembangan level penalaran yang dilakukan dengan studi kasus pada mahasiswa pendidikan matematika STKIP Sebelas April Sumedang dengan materi statistika penelitian.

Bigss dan Collis (1982), mengelompokkan bernalar menjadi empat level taksonomi SOLO (Structure of the Observed Learning Outcome), yaitu idiosyncratic atau prestructural, transitional atau unistructural, quantitative atau multistructural, dan analytical atau relasional. Garfield membagi penalaran statistis menjadi lima level, yaitu idiosyncratic, verbal, transitional, procedural dan integrated. Kemudian, Shaughnessy, J. M., M. Ciancetta, K. Best, and J Noll (2005) mengklasifikasikan penalaran statistik menjadi tiga tahap penalaran yaitu additive reasoning, proportional reasoning, dan distributional reasoning. Kemudian, Reading dan Reid (2006), mengklasifikasikan level penalaran berdasarkan pada Taksonomi SOLO dari Biggss dan Collis (1982) terdiri dari prestructural, Unistructural, Multistructural, dan relational.

Bagaimanakah penjelasan dari masing-masing tingkat itu dan bagaimana kaitannya dengan yang lain? Bagaimanakah pemikiran tingkat penalaran statistis dalam statistika penelitian? Pertanyaan-pertanyaan itu akan dijawab dalam uraian tulisan ini.

\section{KAJIAN PUSTAKA}

\section{Penalaran Statistis}

Penalaran statistis dapat didefinisikan sebagai cara bernalar dengan ide-ide statistik dan memahami informasi statistis (Garfield dan Gal, 1997). Hal Ini meliputi pembuatan interpretasi berdasarkan data, representasi data, dan ringkasan data statistik. Bentuk penalaran statistis menggabungkan ide-ide tentang data dan peluang, yang mengarah pada pembuatan kesimpulan dan menafsirkan hasil statistik. Penalaran ini didasari oleh konsep-konsep penting tentang pemusatan data, rentang, peluang, korelasi dan asosiasi, dan sampling. Kemudian Lovett (2001) menginterpretasikan penalaran statistis sebagai menggunakan alat statistik dan konsep untuk membuat rangkuman, prediksi, dan menarik kesimpulan dari data. Sejalan dengan pendapat Ben-Zvi dan Garfield (2004) bahwa penalaran statistis adalah cara berfikir dengan menggunakan informasi statistik. Sementara del Mas (2002) mengemukakan bahwa penalaran statistis merupakan kemampuan menjelaskan mengapa dan bagaimana suatu hasil di produksi dan mengapa dan bagaimana menarik kesimpulan. Sedangkan Martadipura (2012) mengatakan bahwa penalaran statistis adalah kemampuan siswa dalam mengerjakan perhitungan statistis dan penalaran terhadap konsep statistis.

Chervaney dkk. (Garfield, 2002) mendefinisikan penalaran statistis sebagai apa yang dapat dilakukan siswa dengan konten statistis dan menggunakan keterampilannya dalam menggunakan konsep statistis untuk penyelesaian masalah statistik. Mereka melihat penalaran statistis sebagai proses yang terdiri dari tiga langkah berikut:

1) Komprehensi, yaitu melihat sebagian masalah sebagai masalah yang sama dalam satu kelas.

2) Perencanaan dan pengambilan keputusan, yaitu mengaplikasikan metode yang cocok untuk menyelesaikan masalah.

3) Evaluasi dan interpretasi, yaitu menginterpretasikan hasil dan mengaitkannya dengan masalah asal.

Banyak orang yang bingung dengan statistika dan matematika oleh karena itu mereka memandang penalaran statistis dan matematis adalah hal yang sama. Penalaran statistis dan matematis dapat 
dipandang sebagai dua hal yang berbeda. Pada kasus ini, del Mas (2002) berpendapat bahwa penalaran matematis lebih abstrak sedangkan penalaran statistis lebih kontekstual.

\section{Model Penalaran Statistik}

Beberapa ahli mengembangkan model penalaran statistis (Garfield, 2002, Shaughnessy, J. M., M. Ciancetta, K. Best, and J Noll, 2005 dan Reading and Reid, 2006). Mereka kadang menggunakan istilah penalaran statistis dan berpikir statistis menjadu dua hal yang berbeda dan kadang mereka menggunakan istilah tersebut sebagai istilah yang dapat dipertukarkan. Tetapi, del Mas (2002) membedakan penalaran dan berpikir statistis sebagai berikut. Penalaran statistis adalah kemampuan untuk menjelaskan kenapa dan bagaimana hasil diproduksi atau kenapa dan bagaimana kesimpulan diperoleh. Sedangkan berpikir statistis adalah kemampuan untuk memecahkan masalah nyata dengan kritik, evaluasi dan generalisasi.

Bigss dan Collis (1982), mengelompokkan berpikir menjadi empat level taksonomi SOLO (Structure of the Observed Learning Outcome) yaitu idiosyncratic atau prestructural, transitional atau unistructural, quantitative atau multistructural, dan analytical atau relational. Sama seperti Biggs dan Collis (1982), Garfield (2002) juga memperkenalkan sebuah model penalaran statistis yang mempunyai lima level dan disusun secara hierarkis yaitu idiosyncratic, verbal, transitional, procedural, dan integrated.

Kemudian, Shaughnessy, J. M., M. Ciancetta, K. Best, and J Noll (2005) mengklasifikasikan penalaran statistik menjadi tiga tahap penalaran yaitu additive, proportional dan distributional. Sebagai contoh, untuk memehami konsep variansi melalui pengertian dari frekuensi, itu dinamakan additive reasoning. Kemudian jika memehami berdasarkan pada frekuensi relatif, itu dinamakan proportional reasoning. Tetapi, jika memahami berdasarkan frekuensi relatif dan rentang dari data, maka itu dinamakan distributional reasoning. Kemudian, Reading dan Reid (2006), mengklasifikasikan level penalaran berdasarkan pada Taksonomi SOLO dari Biggs dan Collis (1982) terdiri dari prestructural, Unistructural, Multistructural, dan relational.

\section{METODE}

Metode yang digunakan dalam penelitian ini menggunakan metode kualitatif. Lokasi penelitian bertempat di STKIP Sebelas April Sumedang. Subjek penelitian adalah mahasiswa semester VII yang telah mendapatkan materi statistika penelitian. Penentuan lokasi penelitian berdasarkan tempat bekerja peneliti. Sedangkan penentuan kelas yang terpilih sebagai subjek penelitian berdasarkan tugas mengajar yang diberikan kepada peneliti.

Data utama yang dikumpulkan dalam penelitian ini adalah data dari hasil pelaksanaan tes sehingga soal dan jawaban mahasiswa merupakan data-data yang dianalisis. Dalam penelitian ini, soal-soal yang disajikan pada saat tes tertulis bukanlah sebagai "perantara" yang menerjamahkan fakta ke dalam data (angka-angka) sebagaimana dalam penelitian nonkualitatif. Sumber data utama tersebut berasal dari mahasiswa yang mengikuti tes tertulis. Selain dengan tes tertulis juga dilakukan pengumpulan data melalui angket terhadap mahasiswa, serta wawancara berdasarkan pada hasil tes penalaran statistis.

Pengumpulan data dilakukan dengan triangulasi. Dalam penelitian ini akan digunakan tiangulasi sumber dan metode, sehingga data yang diperoleh akan lebih konsisten, tuntas, dan pasti. Teknik pengumpulan data dalam penelitian ini dilakukan dengan triangulasi yaitu gabungan dari tes tertulis, angket dan studi dokumentasi. Analisis data yang dilakukan menggunakan metode perbandingan tetap (constant comparative method). Secara umum proses analisis data tersebut mencakup: reduksi data, kategorisasi data, sintesisasi, diakhiri dengan hipotesis kerja. 


\section{HASIL DAN PEMBAHASAN}

Berdasarkan level penalaran yang ada, maka akan dilakukan perbandingan. Level penalaran yang ada yaitu Level penalaran statistis dari Biggs dan Collis yang akan disingkat dengan LPSBC, Level Penalaran Statistis Garfield akan disingkat dengan LPSG, Level Penalaran Statistis Shaughnessy dkk yang disingkat dengan LPSS dan Level penalaran statistis dari Reading dan Reid yang akan disingkat dengan LPSRR.

Tabel 1. Perbandingan LPSBC, LPSG, LPSS dan LPSRR

\begin{tabular}{|c|c|c|c|}
\hline LPSBC & LPSG & LPSS & LPSRR \\
\hline $\begin{array}{l}\text { Idiosyncratic atau Prestructural } \\
\text { level. } \text { Pada level ini, cara berpikir } \\
\text { didominasi oleh berpikir ikonik } \\
\text { dan konkrit-simbolik, pada } \\
\text { statistika, sebagai contoh } \\
\text { diilustrasikan pada kemampuan } \\
\text { berpikir tentang pemusatan pada } \\
\text { data yang tidak relevan. }\end{array}$ & \begin{tabular}{lr} 
Idiosyncratic & \multicolumn{2}{c}{ Reasoning. } \\
Mengetahui beberapa istilah \\
dan simbol statistika serta \\
penggunaannya namun tidak \\
sepenuhnya dan sering \\
memberikan jawaban yang \\
tidak akurat & atau \\
memberikan argumen yang \\
tidak relevan.
\end{tabular} & $\begin{array}{lr}\text { Additive } & \text { reasoning: } \\
\text { Kondisi } & \text { dimana } \\
\text { penjelasan } & \text { konsep } \\
\text { berdasarkan r pada } \\
\text { konsep sebelumnya } \\
\text { secara umum }\end{array}$ & $\begin{array}{l}\text { Prestructural: } \\
\text { tidak memiliki } \\
\text { konsep dasar } \\
\text { secara jelas. }\end{array}$ \\
\hline $\begin{array}{l}\text { Transitional atau Unistructural } \\
\text { level. Pada statistik, level ini } \\
\text { diilustrasikan } \\
\text { kemampuan transisi dengan } \\
\text { berpikir idiosyncratic menuju } \\
\text { berpikir quantitative tetapi } \\
\text { secara umum difokuskan hanya } \\
\text { pada satu aspek walaupun itu }\end{array}$ & \begin{tabular}{lr} 
Verbal & \multicolumn{2}{r}{ Reasoning. } \\
Mengetahui konsep, tetapi \\
tidak dapat mengidentifikasi \\
penggunaan & konsep \\
sepenuhnya. Sebagai contoh: \\
dapat mendefinisikan konsep \\
secara tepat tetapi tidak dapat \\
menggunakan konsep tersebut.
\end{tabular} & $\begin{array}{l}\text { Proportional } \\
\text { Reasoning: Situasi } \\
\text { dimana penjelasan } \\
\text { konsep dipengaruhi } \\
\text { oleh beberapa konsep } \\
\text { yang berhubungan }\end{array}$ & $\begin{array}{l}\text { Unistructural: } \\
\text { fokus hanya pada } \\
\text { satu konsep } \\
\text { statistik. }\end{array}$ \\
\hline $\begin{array}{l}\text { kembali pada berpikir } \\
\text { idiosyncratic. }\end{array}$ & $\begin{array}{l}\text { Transitional } \\
\text { Menentukan konsep secara } \\
\text { benar, tetapi aplikasi dari } \\
\text { konsep tersebut tidak } \\
\text { terintegrasi. }\end{array}$ & & \\
\hline $\begin{array}{l}\text { Quantitative atau } \\
\text { Multistructural Level. Pada } \\
\text { statistik, level ini diilustrasikan } \\
\text { dengan kemampuan berpikir } \\
\text { kuantitatif dan untuk membuat } \\
\text { hubungan antara data seperti } \\
\text { untuk menggambarkan, } \\
\text { menyusun, merepresentasikan } \\
\text { dan menganalisis data. }\end{array}$ & $\begin{array}{l}\text { Procedural } \\
\text { Mengidentifikasi secara benar } \\
\text { konsep atau proses statistik } \\
\text { tetapi aplikasi dari konsep } \\
\text { tersebut tidak sepenuhnya } \\
\text { terintegrasi secara utuh. }\end{array}$ & \begin{tabular}{lr}
\multicolumn{2}{l}{ Distributional } \\
Reasoning: & Situasi \\
dimana penjelasan \\
konsep $r$ dengan \\
mengingat $r$ konsep \\
yang lebih & spesifik \\
dan berkaitan.
\end{tabular} & \begin{tabular}{lr}
\multicolumn{2}{l}{ Multistructural: } \\
fokus & pada \\
beberapa & konsep \\
statistik. &
\end{tabular} \\
\hline $\begin{array}{l}\text { Analitical Level atau Relational } \\
\text { Level. Pada statistik, level ini, } \\
\text { diilustrasikan pada kemampuan } \\
\text { untuk berpikir analisis dan } \\
\text { quantitative seperti kemampuan } \\
\text { untuk menjelaskan dengan } \\
\text { berbagai macam perspektif } \\
\text { berdasarkan data. }\end{array}$ & \begin{tabular}{lcr} 
Integrated & \multicolumn{2}{c}{ Reasoning: } \\
memiliki pemahaman yang \\
lengkap & dari & proses, \\
keterkaitan & aturan & dan \\
penggunaan & statistik. &
\end{tabular} & & $\begin{array}{l}\text { Relational: } \\
\text { mengembangkan } \\
\text { hubungan antara } \\
\text { konsep statistik } \\
\text { lainnya. }\end{array}$ \\
\hline
\end{tabular}

Perbandingan LPSBC dengan LPSG, adalah diosyncratic reasoning level pada LPSBC setara dengan level penalaran idiosyncratic pada LPSG. Dimana idiosyncratic level pada kedua model 
penalaran sama-sama siswa hanya dapat menggunakan simbol atau istilah tetapi tidak sepenuhnya penggunaan untuk simbol atau istilah tersebut mereka gunakan dengan tepat. Misal menggunakan simbol $\mu$ untuk menyatakan rata-rata sampel. Transitional reasoning level pada LPSBC setara dengan level penalaran verbal dan transitional pada LPSG. Sejalah dengan pendapat Chance, del Mas, Garfield (Reading dan Reid, 2006: 48) bahwa pada penalaran verbal dibutuhkan untuk menerapkan suatu konsep diperlukan pengetahuan tentang konsep yang lain, misalnya ssiswa tidak dapat menerapkan distribusi sampling hingga siswa menguasai konsep tentang variabilitas dan distribusi. Verbal reasoning level pada LPSG adalah mengetahui konsep tetapi tidak dapat mengidentifikasi penggunan konsep tersebut, maksudnya ketika siswa diberi masalah dia tidak dapat mengerjakan soal tersebut padahal dia mengetahui tentang suatu konsep. Misal, ada permasalahan tentang uji statistika satu sampel, siswa tidak bisa menyelesaikan permasalahan tersebut padahal dia mengetahui konsep tentang uji satu sampel hal ini terjadi karena pada penyelesaian uji statistika satu sampel siswa harus mengetahui konsep uji normalitas juga. Verbal reasoning level ini sulit diukur dengan ujian tertulis, untuk mengetahui level penalaran ini harus dilakukan dengan tes lisan (wawancara). Sedangkan transitional level pada LPSG adalah menentukan konsep dalam penyelesaian masalah namun aplikasi dari konsep tersebut tidak terintegrasi, maksud dari level ini adalah siswa dapat mengerjakan permasalahan yang ada, tetapi tidak mengetahui keterkaitan konsep yang dia gunakan dengan konsep yang lain. Misal, ada permasalahan tentang uji statistika satu sampel, siswa mengerjakan dengan menggunakan uji t (uji parametris). Padahal untuk melakukan pengolahan data dengan uji parametris diperlukan asumsi data berdistribusi normal atau dilakukan uji normalitas terlebih dahulu. Multistructural Reasoning pada LPSBC setara untuk integrated reasoning level dan procedural reasoning pada LPSG, dimana pada multistructural reasoning diperlukan pemahaman yang lengkap dari proses serta keterkaitan aturan penggunaan statistika sehingga dapat melakukan analisis data.

Model LPSRR yang dikembangkan dari LPSBC memiliki kesamaan dengan LPSBC, sehingga dalam hal ini tidak dilakukan perbandingan karena telah diwakili oleh LPSBC. Namun LPSRR lebih singkat, padat dan jelas dalam penjelasan level penalaran statistis. Sehingga mudah digunakan dalam melakukan pengukuran kemampuan penalaran statistis. Secara umum, perbandingan kriteria dari LPSBC, LPSG, LPSS dan LPSRR dapat dilihat pada tabel 2.

Tabel 2. Perbandingan Kriteria LPSBC, LPSG, LPSS dan LPSRR

\begin{tabular}{llll}
\hline LPSBC & LPSG & LPSS & LPSRR \\
\hline $\begin{array}{l}\text { Idiosyncratic/ } \\
\text { prestructural }\end{array}$ & idiosyncratic & & Prestructural \\
\hline $\begin{array}{l}\text { Transitional/ } \\
\text { Unistructural }\end{array}$ & Verbal & Additive reasoning & Unistructural \\
\hline & Transitional & & \\
\hline $\begin{array}{l}\text { quantitativel } \\
\text { Multistructural }\end{array}$ & Procedural & $\begin{array}{l}\text { Proportional } \\
\text { reasoning }\end{array}$ & Multistructural \\
\hline $\begin{array}{l}\text { Relational/ } \\
\text { Analitical }\end{array}$ & integrated & $\begin{array}{l}\text { Distributional } \\
\text { reasoning }\end{array}$ & Relational \\
\hline
\end{tabular}

Dari tabel 6. dapat dilihat bahwa idiosyncratic atau prestructural merupakan tahap dasar dari proses penalaran, dimana diminta menggunakan simbol atau istilah yang sesuai dengan masalah yang disajikan sehingga mempermudah dalam mengidentifikasi masalah. Transitional/ unistructural Level, merupakan proses penalaran yang hanya terbatas pada satu konsep. Pada level ini, siswa tidak mengetahui keterkaitan konsep yang diketahui dengan konsep lain. Adapun konsep yang diketahui dikaitkan dengan pengetahuan yang masih bersifat umum atau dasar seperti simbol dan istilah. 
Quantitative reasoning/ multistructural dari Biggs dan Collis(1982) memberikan gambaran apa yang dapat dilakukan dengan data hingga data tersebut dianalisis. Sedangkan pada Garfield (2002), dalam melakukan analisis data tentunya harus memahami suatu prosedur yang akan dilakukan serta proses terpadu yang menyeluruh dan utuh karena dalam melakukan suatu analisis data dalam statistika penelitian khususnya diperlukan suatu prasyarat atau materi-materi lain. Hal ini sejalan dengan Shaughnessy, J. M., M. Ciancetta, K. Best, and J Noll (2005) yang menyebutkan penggunaan beberapa konsep yang berhubungan sebagai kriteria penalaran proporsional. Kriteria yang digunakan ketiganya secara garis besar memiliki persamaan yaitu menggunakan beberapa konsep dalam penyelesaian masalah statistika yang disajikan. Relational reasoning atau analytical level pada LPSBC mempunyai kriteria menjelaskan dengan berbagai perspektif berdasarkan data, LPSRR mempunyai kriteri mengembangkan hubungan antara konsep satatistika, LPSS mempunyai kriteria mengaitkan pada konsep-konsep yang lebih spesifik.

Kriteria yang diberikan oleh Biggs dan Collis (1982), Shaughnessy, J. M., M. Ciancetta, K. Best, and J Noll (2005) serta Reading dan Reid (2006) memberikan penekanan yang berbeda-beda. LPSS memberikan kriteria yang umum, tidak berlaku untuk statistika penelitian. Kriteria yang dapat digunakan pada statistika penelitian adalah kriteria yang diajukan oleh Biggs dan Collis (1982). Misal, dalam pengambilan kesimpulan dapat dilakukan dengan berbagai perspektif seperti perbandingan nilai hitung dengan nilai tabel atau dengan melihat p-value dengan taraf signifikansi. Sedangkan kriteria yang diajukan oleh Reading dan Reid (2006) sulit untuk diukur dalam statistika penelitian

Proses penalaran statistis terdiri dari tiga tahap seperti yang dikemukakan oleh Chervaney dkk. (Garfield, 2002) yaitu komprehensi, perencanaan dan pengambilan keputusan, serta evaluasi dan interpretasi. Jika mengacu pada proses penalaran statistis berdasarkan Chervaney dkk, kriteria penalaran statistis yang diajukan oleh Garfield dapat digunakan untuk menempatkan seseorang pada suatu level penalaran. Namun, Biggs dan Collis menambahkan satu kriteria yaitu menjelaskan dalam berbagai perspektif berdasarkan data yang ada. Biggs dan Collis berpendapat demikian karena dalam melakukan pelevelan mengacu pada berpikir, sedangkan Garfield mengacu pada materi statistika yang tidak semua masalah yang ada pada statistika dapat dijelaskan dalam berbagai perspektif. Oleh karena itu, penulis melakukan suatu pengembangan pada model penalaran statistis yang dapat dilihat pada tabel 3 .

Tabel 3. Hasil Pengembangan Model Penalaran Statistis

\begin{tabular}{|c|c|c|c|c|c|}
\hline \multirow[t]{2}{*}{ LPSBC } & \multirow[t]{2}{*}{ LPSG } & \multirow[t]{2}{*}{ LPSS } & \multirow[t]{2}{*}{ LPSRR } & \multicolumn{2}{|c|}{$\begin{array}{c}\text { Hasil } \\
\text { Pengembangan }\end{array}$} \\
\hline & & & & $\mathrm{A}$ & $\mathrm{B}$ \\
\hline & & & & LPS 0 & LPS 0 \\
\hline $\begin{array}{l}\text { Idiosyncraticl } \\
\text { prestructural }\end{array}$ & idiosyncratic & & Prestructural & LPS 1 & LPS 1 \\
\hline \multirow[t]{2}{*}{$\begin{array}{l}\text { Transitionall } \\
\text { Unistructural }\end{array}$} & Verbal & $\begin{array}{l}\text { Additive } \\
\text { reasoning }\end{array}$ & Unistructural & LPS 2 & LPS 2 \\
\hline & Transtitional & & & LPS 3 & \\
\hline $\begin{array}{l}\text { quantitativel } \\
\text { Multistructural }\end{array}$ & Procedural & $\begin{array}{l}\text { Proportional } \\
\text { reasoning }\end{array}$ & Multistructural & LPS 4 & LPS 3 \\
\hline $\begin{array}{l}\text { Relational/ } \\
\text { Analitical }\end{array}$ & Integrated & $\begin{array}{l}\text { Distributional } \\
\text { reasoning }\end{array}$ & Relational & LPS 5 & \\
\hline
\end{tabular}


Dengan melihat kesamaan-kesamaan kriteria dalam level penalaran pada alternatif pertama (A), dan untuk selanjutnya disederhanakan berdasarkan data hasil studi kasus yang dilakukan. Maka untuk selanjutnya yang dijadikan teori-hipotetik adalah pada alternatif kedua (B).

Berdasarkan hasil pengerjaan tes penalaran statistis siswa yang berada pada LPS 0, menunjukkan ciri-ciri bahwa siswa tersebut tidak memberikan jawaban dan ada beberapa siswa yang hanya menyalin soal. Siswa tidak dapat mengidentifikasi masalah ke dalam simbol-simbol statistik. Berdasarkan hasil angket dan wawancara yang dilakukan, siswa tidak memberikan jawaban pada soal tes dan tidak dapat mengidentifikasi masalah karena siswa tidak memahami permasalahan yang disajikan dan mereka bingung menggunakan simbol statistika untuk sampel dan parameter, sehingga hal ini menyebabkan mereka tidak dapat mengidentifikasi masalah dan merumuskan hipotesis statistiknya. Hasil pengerjaan siswa pada LPS 0 dapat dilihat pada gambar 1 dan gambar 2.

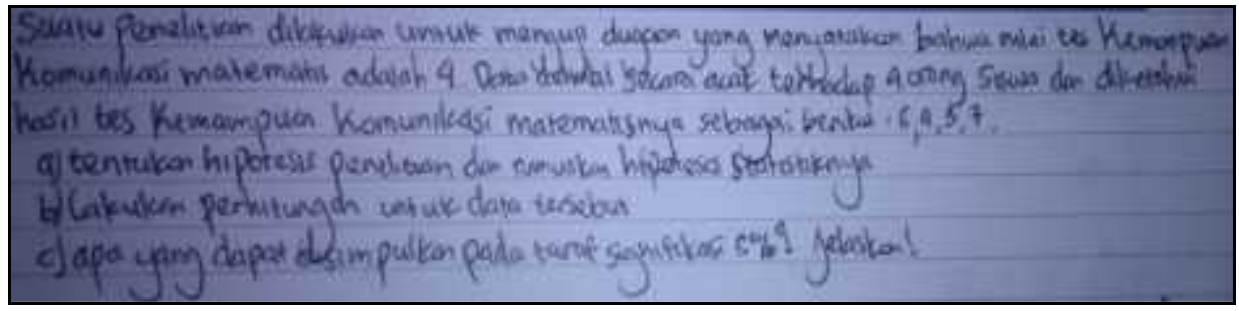

Gambar 1. hasil pengerjaan siswa pada LPS 0(a)

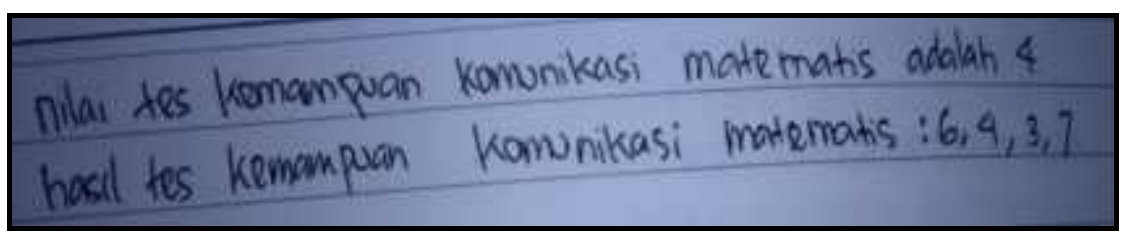

Gambar 2. Hasil Pengerjaan Siswa LPS 0 (b)

Siswa yang mencapai tingkat ini, dinamakan sebagai siswa yang tidak memiliki penalaran statistis.

Siswa pada LPS 1 (prestructural) memiliki ciri hanya dapat mengidentifikasi masalah dengan menggunakan simbol atau istilah serta dapat menentukan hipotesis penelitian. Berdasarkan hasil wawancara dan angket, siswa tersebut kesulitan dalam menentukan rumus mana atau langkah mana yang digunakan dalam menyelesaikan permasalahan yang ada. Karena mereka tidak mengerti harus melakukan apa terlebih dahulu untuk mengerjakan soal tersebut. Hasil pengerjaan siswa pada LPS 1 dapat dilihat pada gambar 3 .

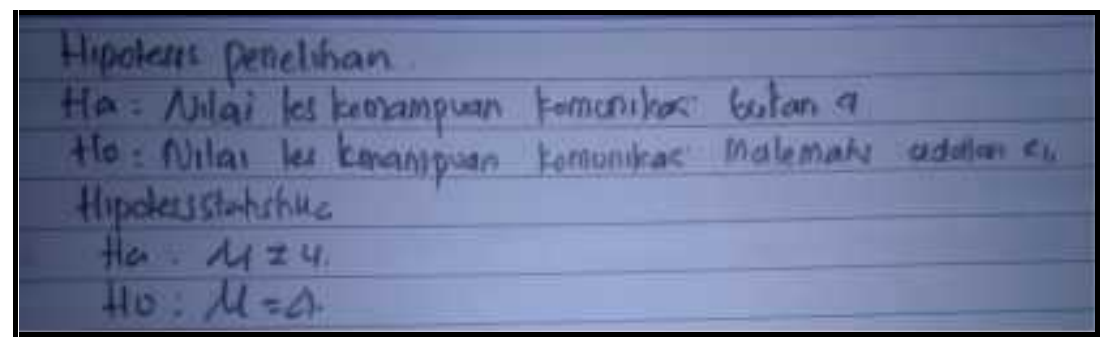

Gambar 3. Hasil pengerjaan Siswa pada LPS 1 
Siswa yang mencapai tingkat ini, dinamakan sebagai siswa yang memiliki penalaran statistis dengan kategori kurang.

Siswa pada LPS 2 (transisi) memiliki ciri-ciri dapat mengidentifikasi masalah dengan menggunakan simbol atau istilah yang tepat, dapat menentukan hipotesis penelitian dan mengetahui konsep apa yang digunakan dalam menyelesaikan masalah tetapi tidak mengerti penggunaan konsep tersebut. Hasil pengerjaan siswa pada LPS 2 dapat dilihat pada gambar 4 dan gambar 5 .

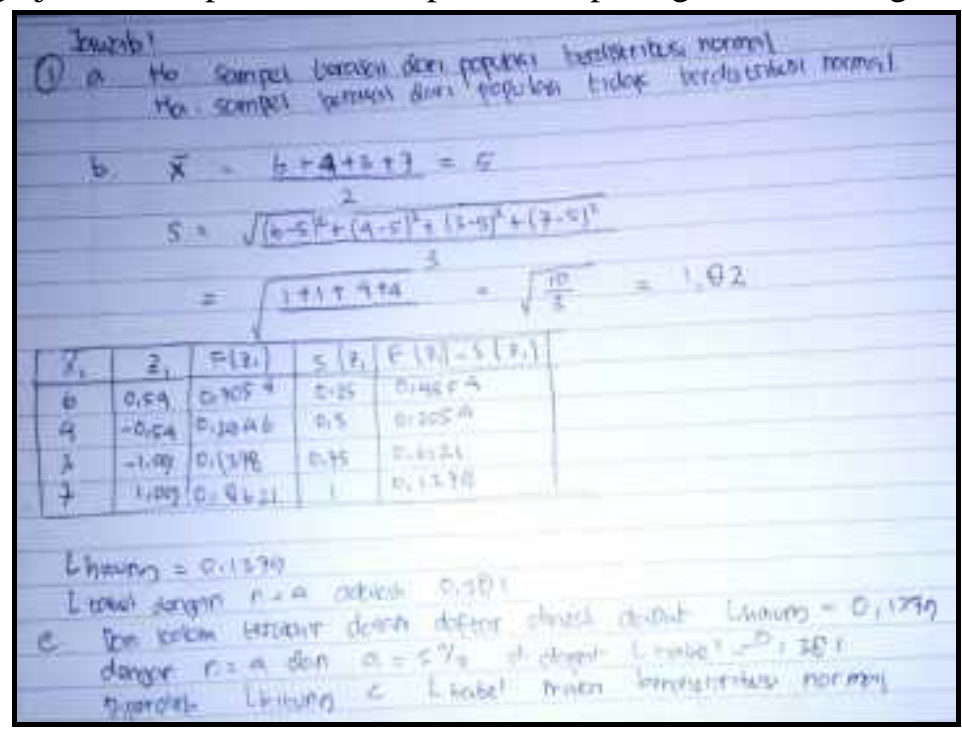

Gambar 4. Hasil pengerjaan siswa pada LPS 2(a)

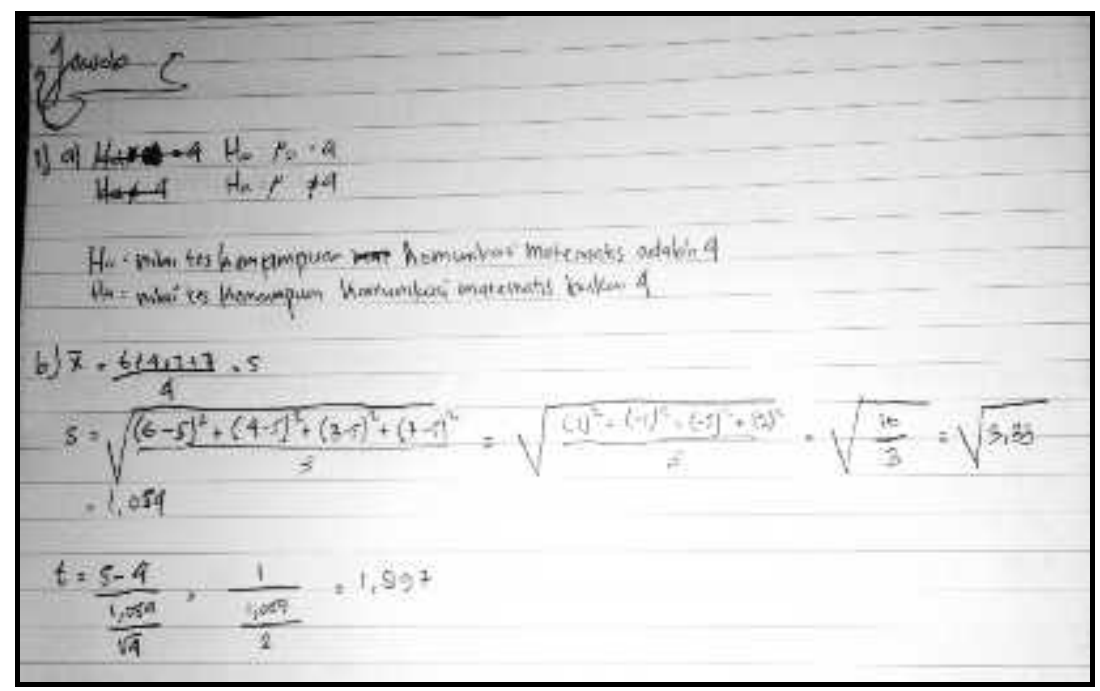

Gambar 5. Hasil Pengerjaan Siswa pada LPS 2 (b)

Pada gambar 4, siswa hanya bisa mengerjakan dengan menghitung uji normalitas saja. Siswa tidak mengerti permasalahan yang terdapat pada soal dan konsep apa yang dibutuhkan dalam meyelesaikan permasalahan yang ada. Artinya, siswa hanya menguasai konsep uji normalitas dan tidak mengetahui konsep-konsep yang lain. Sedangkan pada gambar 5, siswa hanya terfokus kepada konsep penyelesaian masalah (uji t satu sampel), tetapi dia tidak mengerti bahwa untuk dapat melakukan perhitungan uji t dipersyaratkan data harus berdistribusi normal. jadi berdasarkan hasil pengerjaan siswa, dapat diketahui bahwa pemahaman siswa dalam menyelesaikan permasalahan belum terintegrasi secara utuh. Siswa yang mencapai tingkat ini, dinamakan sebagai siswa yang memiliki penalaran statistis dengan kategori cukup. 
Siswa pada LPS 3 (proses terpasu) memiliki ciri-ciri dapat mengaplikasikan konsep dengan benar untuk menyelesaikan masalah dan dapat menginterpretasikan serta mengaitkannya dengan masalah asal (membuat kesimpulan). Hasil pengerjaan siswa pada LPS 3 (proses terpadu) dapat dilihat pada gambar 6 .

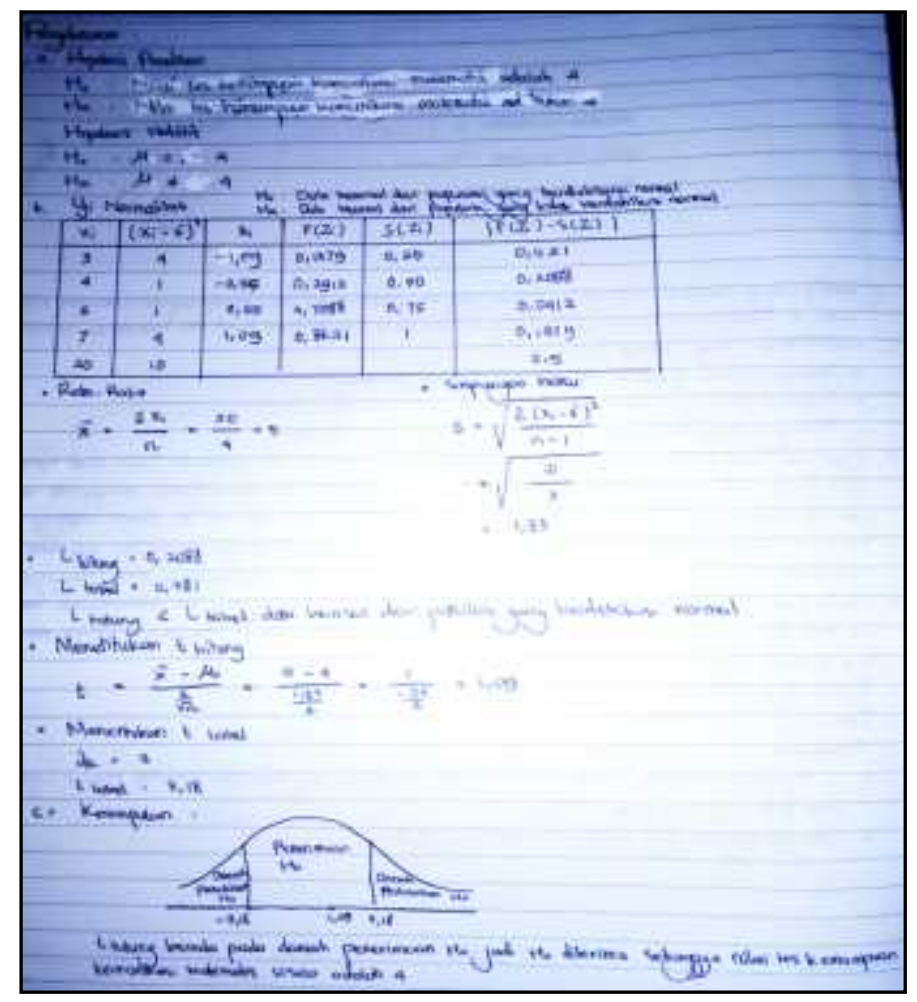

Gambar 6. Hasil pengerjaan siswa pada LPS 3

\section{SIMPULAN DAN SARAN}

Model penalaran statistis yang dikembangkan berdasarkan teori-teori yang diketahui dengan melakukan verifikasi di lapangan (STKIP Sebelas April Sumedang) pada materi statistika penelitian. Dengan demikian pembagian level / tingkat penalaran statistis tersebut dapat berubah atau mengalami perbaikan/penyempurnaan, yang disesuaikan dengan materi atau sampel penelitian.

Hasil pengembangan selanjutnya akan memberikan kontribusi teori dalam menentukan kualitas kemampuan penalaran statistis individu, khusus dalam materi statistika penelitian. Sedang dalam penerapan pembelajaran di kelas dapat berguna dalam beberapa hal. Pertama untuk memprediksi dan mengklasifikasikan kemampuan siswa dalam kemampuan penalaran statistis (khusus statistika penelitian). Kedua untuk merancang model atau strategi pembelajaran yang bertujuan meningkatkan atau mengoptimalkan kemampuan penalaran statistis siswa. Dengan mengetahui rata-rata level penalaran statistis siswa (dalam statistika penelitian) suatu kelas, guru dapat merancang strategi, pendekatan, metode ataupun teknik pembelajaran yang sesuai dan tepat. Ketiga, level penalaran statistis ini dapat menjadi acuan atau patokan dalam penilaian kemampuan (kualitas) penalaran statistis siswa dalam belajar statistika. Terakhir, level penalaran statistis dapat sebagai pedoman dalam mengidentifikasi kelemahan dan kekuatan siswa dalam penalaran statistis. 


\section{DAFTAR PUTAKA}

Ben-Zvi D. And Gafield, J. 2004. The Challenge of Developing Statistical Literacy, Reasoning, and Thinking. (p 121 - 146) Boston MA Kluwer Academic Publisher.

Biggss, J. B. and Collis, K.F. 1982. Evaluating the quality of learning: the SOLO taxonomy. New York, NY: Academic Press.

delMas, R. 2002. Statistical Literacy, Reasoning, and Leraning: A Commentary”. . Journal of Statistics Education, 10(3). [Online]. Tersedia: www.amsat.org/publicatins/jse/ v103/delmas_disscussion.html.

Gal, I dan Garfield,J.B. 1997. Teaching and Assesing Statistical Reasoning. NCTM.

Garfield, J. B. 2002. The Chalange of Develoving Statistical Reasoning. Journal of Statistics Education, 10(3). [Online]. Tersedia: www.amsat.org/publicatins/jse/v103/garfield,html.

Lovett, M. 2001. A Collaborative Convergence on Studying Reasoning Processes. A Case Study in Statistic. In D Klahr and S. Carver (Eds). Cognition and Instruction Twenty-Five Years of Progress (p 347-384). Mahwah: NJ Lawrence Erlbaum.

Martadipura, B. A. 2012. Peningkatan Kemampuan Berpikir Statistis Siswa S1 Melalui Pembelajaran MEAs yang Dimodifikasi. Jurnal Ilmiah Program Studi Matematika STKIP Siliwangi Bandung, 1 (1). Tersedia: http://www.jurnal-infinity.com.

Moore, D. S. 1997. "New Pedagogy and New Content: The Case of Statistics". International Statistics Review, 65(2), 123-165.

Reading, C. And J. Reid. 2006. A Emerging Hierarchy of Reasoning of Reasoning about Distribution: From a Variation Perspective. Statistics Education Research Journal, 5(2), 46-68.

Rumsey, D. 2002. Statistical Literacy as a Goal for Introductory Statistics Courses. Journal of Statistics Education, 10(3). [Online]. Tersedia: www.amsat.org/publicatins/jse/v10n3/ rumsey2.html.

Shaughnessy, J. M. dkk. 2005. Secondary and Middle School Students Attention to Variability when Comparing Data Sets. Paper presentation at The Research Pressesion of the $82^{\text {th }}$ Anual Meeting of The National Council of Teacher of Mathematics, Anahiem. CA. 